\title{
Beyond Frank Willett: The Need for Compositional Analysis of Yoruba Art Objects
}

\author{
Olufemi Joseph Olaleye-Otunla
}

\author{
Eyitayo Tolulope Ijisakin ${ }^{2}$
}

Babasehinde Augustine Ademuleya ${ }^{2}$

\section{Mosobalaje Oyebamiji Adeoye ${ }^{3}$}

\author{
${ }^{1}$ Natural History Museum, \\ Obafemi Awolowo University, \\ Ile-Ife, Nigeria \\ ${ }^{2}$ Fine and Applied Arts Department, \\ Obafemi Awolowo University, \\ Ile-Ife, Nigeria \\ ${ }^{3}$ Materials Science and Engineering Department, \\ Obafemi Awolowo University, \\ Ile-Ife, Nigeria
}

DOI: https://doi.org/10.36941/mjss-2022-0018

\section{Abstract}

Since the pioneering efforts of Frank Willett that examine the Yoruba arts, there remains a yearning gap to holistically investigate the material contents and classification of Yoruba art objects. For proper documentation, information and placement of Yoruba arts, the need for a scientific material compositional analysis of Yoruba arts cannot be overemphasised. This discourse employs a qualitative and evaluative mode of research to emphasize the need, importance and prospects of proper scientific material investigation of Yoruba arts. The study provides information on Frank Willett, the Yoruba people, and relevant studies on the Yoruba arts. It further discusses compositional analysis through the lens of literature, art authentication, and makes a case for authenticating Yoruba art collections. Considering the elegance and importance of African arts and antiquities, the findings of this study show that the provenance of Yoruba art objects has not received adequate attention; this has consequently resulted into illegal excavation, manipulations, and trade of Yoruba art collections. The study concludes that there is utmost importance and necessity for scientific material probing of Yoruba art, if it must go beyond the point where Frank Willett stopped. Hence, the need for all African art historical scholars to prospect for scientific probing of the material contents of Yoruba arts objects.

Keywords: Art authentication, Compositional analysis, Frank Willett, Material culture, Provenance, Yoruba arts 


\section{Introduction}

Frank Willett ${ }^{1}$ was an experienced museum professional, field archaeologist, ethnographer and a leading Professor of African art studies. Willett advanced the course of art historical study of Africa particularly the Yoruba (Willett 1960; 1967a\&b; 2004). Willett collaborated with many international scholars in prospecting for the arts and archaeology of Ife and its environs; he pioneered the use of scientific techniques to study African art materials and the application of scientific statistical methods and analysis (Fleming and Willett, 1976). He made a compendium of all evidence available from excavations of Ife known works of art (Illicit and Approved) with relevant scientific data (Willett, 2004). According to Adepegba (1982), Ife and other Yoruba artistic productions such as wood carvings, metal works, textiles, bead works, and pottery, among others are very outstanding.

The Yoruba is a major ethnic group in West Africa, the over 40 million people are predominantly in Nigeria, where they constitute more than $21 \%$ of the total populace. They have lived in urban kingdoms for over 1500 years with a very strong economy through farming, trading, and art productions. Their artisans such as potters, blacksmiths, woodcarvers, leather and bead workers also contribute to the Yoruba rich economy (CIA World Factbook, 2012).

Ile-Ife is the ancestral home of all the Yoruba people in Nigeria and diaspora; Mullen (2004) refers to the ancient city as the historical, political and religious headquarter of the Yoruba people. According to Abimbola (2006), Ile-Ife is the cradle of life where every inhabitant on earth was created before spreading to other parts of the globe. A visit to Ile-Ife brings one in touch with the nostalgia of the home of the Yoruba progenitor-Oduduwa; and other monuments of historic relevance such as the 16 feet Opa Oranmiyan (Staff of the grandson of Oduduwa), the Lafogido Grove, Olokun Aroni, OluOrogbo Shrine, Ooni Ilare, and Potsherds Pavements at Yemoo Grove (Archibong 2008).

Leo Frobenius' account of the discovery of Ife arts in 1913, with the discovery of some Ife bronze and terracotta heads by Frank Willett and others, gave the realisation that there are great and highly rated artworks in Yorubaland - a fact corroborated by Adepegba (1982). In the early 1950s, archaeologists were the first to consider the significance of African arts and its historical studies. This effort was pioneered by Frank Willett in collaboration with other scholars especially on the arts and archaeology of Ife. The discoveries of Yoruba (Ife) arts after Leo Frobenius' founds includes an accidental discovery of eighteen bronze heads at the depth of about 60 centimeters during a foundation digging at Wunmonije site very close to the Ooni's palace in Ile-Ife (Willett, 1960). Further excavations were made at the Osangangan Obamakin, and Olode Walode sites in Ile-Ife in 1953 by William Fagg, Bernard Fagg, and John Godwin, where fragments of terracotta sculptures were found (Willett 1960). Potsherd pavements, terracotta and bronze shrine objects were also found at the excavations made by Frank Willett at Ita-Yemoo in Ile-Ife, between 1956 and 1957 (Willett 2004).

After the investigations of Ife collections by Frank Willett stopped in Nigeria, efforts to organize the collections were carried out later by the Fagg brothers (William \& Bernard), Ekpo Eyo, Paul Ozanne and Peter Garlake in Ile-Ife museums. In 1969, Ekpo Eyo excavated at Lafogido, Ile-Ife, where the terracotta sculpture of animals wearing royal emblem were found on pots set on the edge of what appeared to be a royal tomb (Eyo, 1970; 1974). However, the work of excavations at Ife continued with Ekpo Eyo, Paul Ozanne (1969) and Peter Garlake (1974; 1977). Naturalistic long-necked heads were discovered by Oliver Myers at excavations carried out at Obameri grove near Oduduwa College IleIfe. Peter Garlake between 1971 and 1972 investigated potsherd pavements in Ile-Ife where some terracotta figures associated with the pavement were unearthed. The periodization of Ile-Ife

${ }^{1}$ Frank Willett (b. 18 August, 1925 - d. 15 June, 2006), (CBE, FRSE) was an Anthropologist; an Ethnographer; Director of Hunterian Museum and art Gallery, University of Glasgow 1976-199o; Curator, Royal Society of Edinburgh, 19921997; Vice-Chairman, Scottish Museum Council, 1986-1989; and a Member of the Scottish Museum. Willett developed the exhibition Treasures of Ancient Nigeria. In 1966, he became Professor of art history, African Studies and Interdisciplinary Studies at the Manchester University. Among his passionate publications are Ife in the History of West African Sculpture (1967); African Art: An Introduction (1971); and, "A Chapter of Accidents: Archaeological Discoveries in Ife" (2006). 
prehistory had received several attentions from scholars: Willett (1967); Ozanne (1969); Eyo (1974, 1977), Drewal (1995); Horton (1992); Ogundiran (2003); Blier (2014), and Babalola (2015).

Drewal (1995) classifies art period in Ife into Archaic Era, before AD8oo when minimalist style monolith combines with iron were made; Pre-pavement Era, AD8oo-AD1ooo when stylized stone and terracotta pieces were produced; Early Pavement Era, AD10oo-ADı20o with elaborately decorated pavements in sherds and stone; refined: idealized naturalism in terracotta and metalwork. Others are the Late-pavement Era, AD120o-AD140o when increasing stylization manifested; Post-pavement Era, AD140o-AD16oo with increasing stylization; Humanism Era, AD16oo till present showing styles of Yoruba art in recent centuries. Hence, by AD8oo, Ife was settled and radiocarbon dating of various Ife discoveries indicates that the naturalistic style flourished between 11th and 15th Centuries, lending credence to the fact that Yoruba civilization could be dated as far as 800 AD. Ile-Ife's origin can be traced to around $35 \mathrm{oBC}$ and very significant in the lines of the Yoruba who constitute a major ethnic group in Nigeria, and one of the largest in the continent. Ile-Ife can boast of many tourist centers which are important artistically and archaeologically.

Yoruba (Ife) arts constitute a cynosure and eye-popper of the African arts. Adepegba (1982) expounds greatly on Yoruba art productions; Frobenius (1913) argues that the Yoruba are much more, compared with the ancient Greeks because of the complexity of their cosmology, impressive pantheon, and their arts with the first sets of antiquities discovered in Ile-Ife that were bronze and terra-cotta heads in 1909 and 1938 respectively. Between 1985 and 2015, archaeologists and material composition analysts such as Adeduntan J., Omotoso Eluyemi, Lankton, Ige \& Rehren, Babatunde Babalola, Akinwumi Ogundiran, Adisa Ogunfolakan, and Gerard Chouin blazed the trail again to further investigate the archaeology of Yoruba arts. In addition, Suzanne Preston Blier's (2014) art historical efforts which summed-up in "Art and Risk in Ancient Yoruba: Ife History, Power and Identity C.130o" is commendable. Notwithstanding, there are many Yoruba art collections in Nigeria and overseas; with a yearning gap in their provenance and material composition analysis. In addressing such similar experiences, some museums around the world have introduced programs of studying art objects in their collections.

\section{Compositional Analysis Through the Lens of Literature}

In Africa, south of the Saharan desert, the description, history, as well as the provenance studies of artworks, dating, and material compositional analysis remained elusive. After Frank Willett, art historians in Africa have not given the needed attention to provenance determination of African arts due to lack of funds, facilities, expertise, as well as relevant institutional will-power. At present, there is a dearth of studies on material composition analysis of museum objects and heritage in Nigeria. There are a lot of archaeological sites, local craft industries, potsherd pavements and museums in Nigeria with a very large collection of artifacts whose provenance are yet to be studied. Olabanji et al. (1990) attempted a correlation of elemental patterns of Esie stone figures with surrounding rocks using PIXE and XRF techniques; Ige and Asubiojo (1991), and Ige et al. (1998) investigated the composition analysis and use of soapstone. Ige and Swanson (2008) examined provenance of Esie (Yoruba) soapstone figures using a JEOL JXA 8600 Super probe to determine mineral composition; and Ige, Ogunfolakan and Ajayi (2009) used ICP-MS in the analysis of the chemical components of some potsherd pavements across Yorubaland, southwest Nigeria.

Other studies identified in compositional analysis, museum research and heritage management in Nigeria include Adeduntan (1985), Eluyemi (1987), and Babalola (2011 \& 2015) who investigated the technology of early glass bead production in Ile-Ife; Eluyemi and Babalola focused on evidence from Igbo Olokun. Lankton, et al (2006) focused on early primary glass production in Southern Nigeria. Further, Olorunfemi et al. (2015) investigated Yemoo Grove archaeological site in Ile-Ife. Chouin \& Ogunfolakan (2015); Blier (2015); and, Olaleye-Otunla's (2018) material compositional analysis of selected pottery objects in Ita Yemoo museum collection, Ile-Ife, have also contributed richly to knowledge. The aforementioned studies underscore the relevance of material compositional analysis 
and the need to fill the gap created in advanced museum research and heritage management.

\section{Discussion}

Since 1905, African art enjoyed much attention when European Avant-garde artists of the 2oth Century discovered the richness of African art forms and styles (Bascom 1938; Willett 1960). The social contexts in which African arts function, their meaning, and material content information were not the prerequisite of African arts collectors and historians (Lewis 1990). This development made African arts to be considered part of anthropological studies alone, while African art historical studies were not considered at all before the 1950 .

The development of African art historical studies did not just develop on-site, it emanated from the period of its discovery by the Europeans but with attendant problems. Vansina (1984) argues that at the arrival of African art objects in Europe by 1470, African arts were regarded as curios: that is, strange and interesting objects which invoke inquisitiveness. As time went by, the knowledge and attention for African art deepened and regard for artworks from Africa, south of the Saharan desert increased. By the late 18th Century, artworks from Africa were acquired by museums all over Europe as specimens for material culture. Arising from this development was the Benin punitive expedition by the British in 1897. The storehouses of museums and private collections in Europe and overseas served as repositories for thousands of artworks from Africa for many years; some of the outstanding African arts and objects were thus secured from destruction, despoliation, theft, and vandalism. Nevertheless, there arose some developmental problems in African art historical studies such as material compositional studies of works of art and antiquities.

In regular repository (museum), artworks collected are documented: date of collection, place of origin and other relevant data labels are prerequisites to storage. When a large number of artworks are collected, their data present reliable bases for a sound framework for investigation and historical studies; the results therefrom eventually set canon for fixing other undocumented works from the field. This systematic referencing of works of art in terms of the dating, description, and their relationship to each other in a particular collection constitutes a cataloging system which is useful for historical studies about such collection.

Institutions that cater for works of art such as the museum embrace all aspects of the study. Whatever artist produces end up in private collections, galleries or museums. In Nigeria, museums are under the aegis of the National Commission for Museums and Monuments. Notable museums in Yorubaland (South-Western part of Nigeria) include the Ife National Museum of Antiquities, established in 1948 but opened to the public in 1954; it houses many discovered artifacts in Ile-Ife. There is also the Ita-Yemoo Pottery Museum in Ile-Ife which houses a collection of Yoruba pottery; others are the Museum of Natural History; and, the Martins Aworinlewo Museum of Cultural Antiquities in Obafemi Awolowo University, Ile-Ife. In Ibadan, there is a Museum of Unity that is dedicated to the collections of artifacts from three major ethnic tribes (Yoruba, Igbo, and Hausa) in Nigeria. Several Yoruba palaces and shrines are also homes to small museums that take care of heritage objects.

Nowadays, museums, collectors and gallery owners around the globe consider it very important to do holistic studies of objects in their collection and any about-to-be-collected items; this became necessary to forestall some problems encountered today in the art world. Major problems bedeviling the art world today are art forgery, despoliation, authentication, misidentification, fake, theft, vandalism, fraud, art jurisprudence, and lack of genuine art historical analysis. In the case of these aforementioned problems, material compositional analysis of such artworks becomes highly imperative. Vansina (1984) posits that the job of art history is to answer the question of authenticity, where and when the artwork was produced, who was the artist, what is the system/technique and style of production, why was the work produced, examine the idiosyncrasies and meaning(s) embedded in the work, and elucidate the socio-cultural context and relevance of the art object.

The exact nature of a particular material used for a work of art is much relevant today. What is 
in an artwork? Where does it come from? How was it made? What material constituents led to such creativity? Can such material be identified and differentiated from others within the same source or could be recognized with another from a different source? Frank Willett was the first to use an approach of archaeological, anthropological, as well as material content information to yield comprehensiveness of investigation useful for a complete art historical study. As part of the contextual analysis, defining art objects with their corresponding material compositional information provides an indelible registration mark for such works of art far above a cursory recognition. For a comprehensive investigation and description of African works of art for historical and critical studies, provision of material compositional information will constitute a synergy of the relationship between the genetic and immanent stages of formal analyses of the works of art.

In line with the above submissions, the compositional analysis of Yoruba arts will thus provide the details of raw material content and technology used in the creation, and other influences surrounding such works of art. Thus, work of identification, documentation and the study of Yoruba artifacts will be comprehensive when all these are considered. With these in place, the chronology of Yoruba artifacts- whether absolute or relative can be arranged. Therefore, for a comprehensive historical investigation of Yoruba arts, authentication of the art collections is a necessary imperative.

\section{On Art Authentication}

Authentication is a process or action that validates something to be true, gives credence to genuineness, source, or origin of an object. It could further be seen as fact, true in substance, or in congruent with what something claims to be in terms of origin, authorship, and, as being genuine (The Oxford English Dictionary). Art Authentication started after the Renaissance around 14th Century, there had been great growing interest in antiquities; materials brought-in from distant nations contributed to the increase in the monumental value of works of art and antiquities. The works of deceased artists and other artistic production of the past became more relevant and heavily sought after. The awareness created from this development generated an upsurge in value and acquisition of art objects from Africa into Europe, thus resultantly extended to the contemporary times.

The process which seeks after a general understanding of art connoisseurship, trade, theft, historical importance, curatorial, legal, ethical, with analytical dimensions coalesced into what is known as art authentication. The ever-developing art investigation today is multi-disciplinary which calls for special analytical skills, training, facilities, policing and prosecution of sharp practices. All over the world, several disciplines have also been identified with the art industry such as trade, storage, and management. For example, art historians, criminologists, law enforcement agents, analytical chemists, forensic experts, conservationists, legal authorities, and prosecutors among others are now stakeholders in the art industry.

Authentication has the main thrust, with a clear understanding of what an original work of art entails from many dimensions, that is, from art historical perspective, the legal points of view, as well as the material science interpretations. The effects of art fraud, identification, documentation, despoliation, art industry, and individual artists can never be underestimated. For art authentication practices, generating art authentication theory and practices, understanding analytical investigation and legal position on art are necessary. Expectedly, this creates an interdisciplinary initiative between art, science, conservation, legal institutions, and museums.

In the management of cultural heritage and antiquity materials, there are special implications for litigators, the police, government, museologists, art historians, legal institutions, and other stakeholders in heritage management. Today's sophistication in technology has made the manipulation of things to be very easy. According to Mazurkewich (2000), ascertaining genuineness and originality becomes a challenging issue for the art industry; for instance, fakes and more recent versions and highly-priced Chinese ceramics of Yuang or Ming dynasties have been exposed to X-rays to feign Thermoluminescence results by fraudsters. This brings to the fore, the need to authenticate 
various art collections for their material compositional information.

When art authentication is carried out about a particular collection, there is the possibility of the reduction in art theft and pilferage; this will discourage sharp practices in art sales and to an extent boost art trade when genuine (authenticated) works of art are on sale. Again, when there are issues after insurance and litigations on artworks, authentication is a precondition to admitting evidence in a court of law, that is, showing that a shred of particular evidence is what its advocate claims. Therefore, the art litigator needs to understand how artwork is authenticated because it is going to be the basal evidence required by the Insurance Brokers and the Law Court (based on a particular context and content on a work of art) to ascertaining the genuineness of claims.

\section{Making Case for Authentication of Yoruba Art Collections}

In this $21^{\text {st }}$ century, two developments necessitate the investigation of Yoruba art collections after Frank Willett's approach of combining archaeological, anthropological and material compositional studies: these are the methodological and technical reasons. Methodologically, the material compositional analysis had become part of provenance investigation. Arnold et al. argue that provenance scholars are apt in their postulations that compositional analysis (fingerprint) could connect artifacts to their corresponding material services. Technically, the development of analytical equipment for a better understanding of material content information of works of art is now being used for provenance studies. The analytical science has been revolutionized with the use of precise, sensitive analytical tools. For instance, it has been argued that analytical techniques such as Atomic Absorption Spectophotometry (AAS), Proton Induced X-ray Emission (PIXE), Stable Isotope Analysis (SIA), and Ultraviolent Fluorescence (UF) among others are being employed to authenticate evidence and probe into material composition of art objects (Tykot, 2004; and, Stulemeijer, 2011).

Prospecting further for Yoruba arts after Frank Willett's model will present a proven case of successful integration of analytical, archaeological, archaeometrical, geological, and anthropological methods to solve art historical problems. Benefits derivable from such prospection include a typological record of all Yoruba arts that will enable Yoruba art collections to be classified into articles of domestic use (utilitarian), religious use, articles of pride and prestige, ephemeral materials, and so on. The artistic prominence of Yorubaland cannot be overemphasised because of the discoveries of naturalistic sculptures of terracotta; moreover, stone and bronze sculptures in Ile-Ife challenged the European world about 'primitive' and African arts (Eyo, 1977; Blier, 1990).

Yoruba worldview regarded Ile-Ife as the source of the human race with the attached measure of religious and political importance. Particularly of interest to Yoruba art collection should be the material composition information of artworks from Ile-Ife and its environ, as well as other parts of Yorubaland (after Frank Willett's efforts) that are yet to be investigated, with the aim of plugging the gaps in Yoruba art history. There is an increasing demand for a general account of Yoruba art yet to be published. The attempt at getting close to summarizing factual knowledge of the ancient historical art of the Yoruba is not yet in place. According to Willett and Fleming (1976), the documentation of Yoruba artifacts and antiquities were lacking in the context in which they were made, found, buried and excavated. Thus, an extensive study of Yoruba works of art has not progressed because of the limited understanding of the genres; moreover, sources of some Yoruba works of art remained an enigma. Beyond conjecture, their meaning and significance are still mysteries- the bead-making tradition in Ife, bronze and copper-alloy castings across Yorubaland are notable examples.

From the foregoing, the use of traditional methods of art historical investigation of Yoruba arts collection will be a difficult venture. Reliable judgments and attributions of the specific origins of raw materials used, the objects, as well as the artist who made the objects will also be a serious task. Also in jeopardy are reasons why the objects were made in terms of the contextual and circumstantial evidence of their production, collection, history, as well as the sequences of the order of their former owners and custodians. For Yoruba arts collection in many museum stores across the world, little or no documentation may be available (in form of inventory) that could show attributes that are due to 
each object which may have fallen along a continuum of very uncertain to relatively certain in terms of their sources of origin. In addressing these problems, detailed technical studies of the objects are needed to determine the exact nature, material content, sources of materials, as well as possible ethno-anthropological attributes that may assist in their art historical investigations.

Attempt at investigating Yoruba art should start with a visual examination of the art objects, looking at the sizes, surface and other structural indices like iconography and iconological details supplemented with the radiographic examination. Core materials from the art objects could be sampled for material (content) compositional information. Principal Component Analysis (PCA) of the data could be carried out to interpret the datasets in consonance with art historical attributes (though there are other analytical tools other than PCA for statistical analysis). The provenance of the Yoruba art collections in museums will thus be carried out for storage in databases and modern cataloging systems.

\section{Findings}

This discourse is motivated by the need for scholarly investigation and material compositional analyses with scientific bases for categorization, description, and conservation of Yoruba cultural objects, antiquities, pots and pottery objects, stone and terra-cotta that constitutes most of the Yoruba collections in museums and outside Nigeria. Across Nigerian and overseas museums, there are numerous Yoruba arts in storage and on display: wood, ceramic, terra-cotta, brass, bronze, brass, ivory, stone and glass objects of traditional and contemporary times that are yet to be investigated, described, and classified. With particularity, Ita-Yemoo Pottery Museum, Ile-Ife was established to house pottery objects from the geographic spread that covers all the Yoruba speaking areas in Southwestern Nigeria. The collections of majority of the art objects in Ita-Yemoo Pottery Museum were done by Ulli and Georgina Beier in the early 1970 s but without their corresponding art-historical notes and documentation (Areo \& Areo 2011).

Looking at the material compositional information of Yoruba arts, African art historians have neglected material compositional studies of Yoruba arts; the true origins of many Yoruba art objects are yet to be determined. Considering the sophistication and attention given to the use of terracotta, bronze and copper alloys in Yoruba arts, the same has not been extended to Yoruba potteries, textile works, as well as the traditional beads of Ife. There are no available indications that any major research has been done to determine the material composition analysis and provenance of Yoruba art objects.

Sadly though, the high values attached to African arts and antiquities have encouraged illegal excavation, forgery, acquisition, and trade of works of art on a large scale. Concealing of facts about excavation, acquisition and trade origins by Yoruba art collectors have compounded the problem. African artists and collectors, as well as their European cohorts, are aiding the illicit business: works offered for sale do not conform to their purported origins, or with speculated dating. Regrettably, collectors, curators, and custodians of Yoruba artworks come into the art market and collection forum, creating warp art historical information about objects in their possession. At times, some publications on Yoruba art objects have also been stage-managed and influenced by art dealers to boost the trade and the veracity of objects in their custody - an act attributed to chauvinism. The provenance of Yoruba art objects remained unattended to for some time; and if done at all, it remained questionable now. Therefore, the veracity and otherwise of Yoruba arts collection needs to be carried out with forensic and specialized laboratory tests.

Many a times, museum specimens are known to have been removed out of their context during collection exercises: the history of objects, raw materials used and their movement in time and space are needed to unravel the circumstances and reasons behind their production. Today, many institutions dealing in artworks have institutionalized provenance projects to help determine the authenticity of works of art in their collection: their historical importance, legitimacy, movement over time and people that might have had contacts with such works of art. Examples of such 
provenance projects can be found in the Metropolitan Museum (TMMA-PRJ), and Harvard University Art Museum (HUA-MPR). Today's repositories, archives, and museums collect artworks and generate databases for such collections, and if database must be generated for provenance, it must be done scientifically. Today, information has had a great role in our society and its control is very significant for individuals, organisations, and countries. Vansina (1984) asserts that "it is not enough to describe an object as it is seen; the description should establish the medium..., and unfortunately, that is the usual situation in African art- a cursory inspection is desired to be enough, but it is not. Only laboratory analysis will settle such matters"

The exploration and use of material compositional information in Yoruba art historical studies have received little attention. Yoruba art historical emphasis had been on formal analysis, iconography and ethnographic contexts alone; little attention is given to medium examination and technological investigation of the material content of works of art. Ignoring what is the nature of a material in an artwork, and how it is different from other ones constitutes a rupture of the genetic relationship between a work of art, the material used, and any of its identifiable constituents.

The provenance of traditional Yoruba artworks is more difficult in that most names of indigenous artists are not known, even up till today. Regrettably now that Yoruba art objects have assumed items of a commercial entity and high monetary value, the identity of an artist has now become tangential to the production of works of art. Only paintings and sculptures are given attention (Ijisakin 2019) in Yoruba art studies, worst still is the case of Yoruba ceramics and pottery, which for instance, points attention to the necessity of investigating Yoruba pottery collection in ItaYemoo Pottery Museum in Ile-Ife. One of the crafts greatly practiced among the Yoruba is pottery, and there are a lot of archaeological sites, local pottery industries, potsherds, potsherd pavements and museums in Yorubaland that have a very large collection of pottery artifacts yet to be investigated. Apart from wood carvings, bronze, brass and terracotta works, pottery had projected Yoruba arts into limelight. In the study of Yoruba arts, terracotta objects seem to have received a little attention, but with the exclusion of pottery.

\section{Conclusion}

It is observable that currently, close to non-detailed or holistic research has been conducted on the available Yoruba art objects to ascertain their material constituents. This discourse therefore argues for more research on various museum objects of Yoruba origin that are locked-up in museums and stores all over the World; this will help to plug the gap of not taking geopolitics of knowledgegeneration in visual art scholarship very seriously, a concern articulated by Simbao et al (2017). Further, more research on various museum objects of Yoruba origin would curtail the proliferation of incomplete/distorted historiography of Yoruba art objects, an issue that calls for serious concern as raised by Opuku (2017). There is also the need for a research foundation in Nigeria that will challenge art historical scholars and researchers to consider the use of detectors to enhance the development and course of art historical studies of Yoruba art, as this would enhance the value of the artworks.

Hopefully this discourse will be a springboard for more art history researches in Nigeria using the probe technology of the physical sciences. The other reasons why material content analyses of Yoruba arts is important are the illegal excavations that abounds in Nigeria and especially in Ile-Ife which have made the place unsafe for antiquities; looting and destruction of scientific data which may have resulted from such illegal operations. This paper underscores how best institutions and stakeholders in art historical developments such as museums, galleries, repositories, archives, collectors, among others will aid Yoruba art historical studies with scientific probing techniques. This paper, therefore, recommends the material investigation of all the available artifacts, sadly though, many of the Yoruba art objects have not survived.

Comprehensive and holistic studies of material composition analysis for Yoruba art have not been carried out in Nigeria. This discourse seeks the need for the examination of Yoruba arts because of the prospects derivable from such an exercise for art historical studies. In Nigeria, and probably 
elsewhere, museum artifacts seem to suffer despoliation, degradation, documentation, conservation, provenance and analytical studies of the material composition of artworks. Yoruba pottery for instance, is understudied compared to sculpture, painting, and architecture; whereas pottery is of great importance to ceramists, archaeologists, museum experts, and conservators among others. This is due to the fact that pottery provides valuable information for the understanding of the several aspects of the past, the nature, and origin of objects, their production techniques and possible transfer of technology. Today, new standards of evaluating art historical studies are projected; identification of designs, interpretation of decorative patterns, cultural symbolism and meanings have been developed in addressing the grey areas of inconsistencies and scholastic interpretations in art historical study. Despite the fact that some works of art are dated, others such as Yoruba (Ife) copper-alloy castings, beads, terra-cotta among others, and their provenance are yet to be investigated. There is therefore a compelling need to further investigate Yoruba arts after Frank Willett, so as to erase avenues for conjectures about Yoruba Arts.

\section{References}

Abimbola, K. (2006). Yoruba Culture A Philosophical Account. United Kingdom; Iroko Academic Publihers, 30 36.

Adeduntan, J. (1985). Early glass bead technology of Ile-Ife. West African Journal of Archaeology, 15: 165-171.

Adepegba, C. O. (1982). Ife art: an inquiry into the surface patterns and the continuity of the art tradition among the northern Yoruba, West African Journal of Archaeology, 12, 16-21.

Archibong, M. (2008). Exploring Ile-Ife. Daily Sun = http://.www.sunnewsonline.com/webpages/features/travels/ 2008/Jun/12/Travel-12-06-o8-0o1.htm-retrieved on June12, 2008, 11:29:15PM.

Areo, A. B. \& Areo, M. O. (2011). Beauty and Robustness of Hand-Built Open-Fired Pottery.Nigeria: Cephas Prints Production, p. ix.

Arnold, D. E., Neff, H., Bishop, R. L., (1991). Compositional analysis and "sources" of pottery: an ethnoarchaeological approach. American Anthropologist 93, 70-90.

Arnold, D. E., Neff, H. A., Bishop, R. L., Glascock, M. D., (1999). Testing interpretive assumptions of neutron activation analysis Contemporary pottery in Yucatán, 1964 - 1994. In: Chilton, E.S. (Ed.), Material Meanings, Critical Approaches to the Interpretation of Material Culture. University of Utah Press, Salt Lake City, 61-84.

Babalola, A. B. (2011). Archaeological Investigation at Ile-Ife, Southwest Nigeria: A Preliminary Report on the 2010 Test Excavations. Nyame Akuma 76: 33-46.

Babalola, A. B. (2015). Archaeological Investigations of Early Primary Glass Production at Igbo Olokun, Ile-Ife (Nigeria) (Ph.D. Dissertation, Rice University, Houston).

Bascom, W. (1938) Brass portrait heads from Ile-Ife. Man 28: 176.

Blier, S. P. (1990). African Art Studies, at the Crossroads, An American Perspective In African Art Studies: The State of the Discipline, $91-107$.

Blier, S. P. (2014) Art and Risk in Ancient Yoruba: Ife History, Power, and Identity, C. 13oo. USA: Cambridge University Press.

CIA World Factbook: "Nigeria-Yoruba" (2012 estimate).

Drewal, H. J. (1995) Yoruba-Nine centuries of African Art and Thought, The Centre for African Art, N.Y., p. 46.

Eluyemi, O. (1987). The Technology of Ife Glass Beads: Evidence from Igbo Olokun. Odu, New Series 32: 197-220.

Eyo, Ekpo (1970). 1969 Excavations at Ile-Ife. African Arts 3, 2: 44-47, 87.

Eyo, Ekpo (1974). Excavations at Odo Ogbe Street and Lafogido, Ife, Nigeria. West AfricanJournal of Archaeology 4: 99-109.

Eyo, Ekpo (1977). Two Thousand Years of Nigerian Art, Ethnographica, London.

Frobenius, L. (1913).The Voice of Africa. London: Hutchinson and Co., 88.

Garlake, P. S. (1974). Excavations at Obalara's land, Ife, Nigeria. West African Journal of Archaeology 4: 111-148.

Garlake, P. S. (1977). Excavations on Woye Asiri Family Land in Ife, Western Nigeria. West African Journal of Archaeology 7: 57-95.

Horton, R. (1992). The economy of Ife from ca. AD 9oo - AD 170o. The Cradle of a Race, Sunray Publications, Lagos, $122-147$.

HUA-MPR.-Harvard University Art Museums. Provenance research http://www.artmuseums.harvard.edu/researc $\mathrm{h} /$ provenance/index.html. 
Ige, O. A., Ogunfolakan, B. A., Ajayi E. O. B. (2009).Chemical Characterization of some potsherd pavements from parts of Yorubaland in Southwestern Nigeria. Journal of Archaeological Science 36 (2009) 90 - 99.

Ige, O.A. \& Asubiojo.(1991).Trace element Geochemistry and Petrogenesis of Some metaultramafites in the Apomu and Ife-Ilesha areas. Chemical Geology 91:19-32.

Ige, O. A., Okrusch, M., Schuller, U., Smacdicke, E., and Cook, N. (1998). The metamorphic mafic-ultramafic rocks of Ife-Ilesa Schist Belt, SW. Nigeria. African Journal of Geo., Paris vol.26: 593-618.

Ige, O. A., Swanson, S. E. (2008). Provenance studies of Esie sculptural soapstone fromsouthwestern Nigeria. Journal of Archaeological Science 35. 1553- 1565. Elsevier Ltd

Ijisakin E. T. (2019). "Printmaking in Nigeria: its evolution and developmental history" Academic Journal of Interdisciplinary Studies, 8 (2) 247-26o. Mediterranean Center of Social and Educational Research, Rome.

Lankton, J. W., A. Ige and T. Rehren (2006). Early primary glass production in southern Nigeria. Journal of African Archaeology 4, 1: 111-138.

Lewis, P. H. (1990). A Definition of Primitive Art 1, Fieldiana Anthropology, Vol.36, No.1o, Chicago Natural History Museum, pp.231-232.

Mazurkewich, K. (2000). Art \& Money Section, Wall Street Journal, September 1 (2000).

Mullen, N. (2004). Yoruba Art \& Culture. Phoebe A. Hearst Museum of Anthropology and the Regents of the University of California, Berkeley.

URL=mhtml: file ://E:|Yoruba Art \& Culture.mht retrieved 5 May 2010.

Ogundiran, A. (2003). Chronology, material culture and pathways to the cultural history of the Yoruba-Edo region, 500 BC - AD 180o. Sources \& Methods In African History; Spoken, Written, Unearthed, 33 - 79.

Olabanji, S. O., Olanrewaju, V. O., Onabajo, O. O. (1990). PIXE analysis of museum soapstone sculptures from Esie, Southwestern Nigeria. Nuclear instruments and methods in Physics Research B47, 415-420.

Olaleye-Otunla, O. J. (2018). Material compositional analysis of selected pottery objects in Ita Yemoo museum collection, Ile-Ife. Unpublished M.Phil Dissertation, Ile-Ife: Fine and Applied Arts Department, Obafemi Awolowo University.

Olorunfemi, M. O., Ogunfolakan, B. A., Chouin, G. L., Oni, A. G., Okunubi, O. M., and A. S. Akinwumiju (2015) Integrated geophysical investigation of Yemoo Grove archaeological site in Ile-Ife, Osun State, southwest Nigeria. Ife Journal of Science 17, 3:553-563.

Opuku, Kwame (2017). Can an English artist use classical Nigerian art as he likes? https://www.pambazuka.org/artsbooks/can-english-artist-use-classical-nigerian-art-he-likes

Ozanne, P. (1969). A new archaeological survey of Ife. Odu, New Series 1: 28-45.

Simbao, R., Miko W. B., Ijisakin E. T., Tchibozo R., Hwati M., Ng-Yang K., Mudukereza P.,Nalubowa A., Hyacinthe G., Jason L., Abdou E., Chachage R., Tumusiime A., Souza S., and, Muchemwa F. (2017). "Reaching Sideways, Writing Our Ways: the Orientation of the Arts of Africa Discourse" African Arts, 50 (2) 10-29. Los Angeles: UCLA James S. Coleman African Studies Center, University of California, USA.

Stulemeijer, R. (2011). Provenance Research on $14^{\text {th }}$ Century Greenware found in Singapore, Nalanda-Sriwijaya Centre Working Paper No.9 (Dec 2011), 7. https://www.ideas.edu.sg/nsc/documents/working_papers/nscwp soog.pdf The Oxford English Dictionary (2nd ED.) O.U. P., pp. 795-796, 1989.

TMMA-PRJ. The Metropolitan Museum of Art Provenance Research Project. http://www.metmuseum.org/colle ctions/department.asp?dep $=22 \&$ full $=1$.

Tykot, R. H. (2004). Scientific methods and applications to archaeological Provenance studies. Proceedings of the International School of Physics “Enrico Fermi” Course CLIV, M. Martini, M. Milazzo, and M. Piacentini (Eds.) IOS Press, Amsterdam.

Vansina, J. (1984). Art History in Africa, London, and New York: Longman, pp. viii, 3, $19,24$.

Willett, F. (1960). Ife and Its Archaeology. The Journal of African History 1 (2): 231- 248.

Willett, F. (1967a). Ife in the History of West African Sculpture, London, Thames, and Hudson;New York, McGrawHill.

Willett, F. (1967b). Ife in Nigerian art, African Arts, 1(1), 30-35 and 78.

Willett, F. (2004). The Art of Ife: A Descriptive Catalogue and Database. CDROM, University of Glasgow.

Willett, F. \& Fleming, S. J. (1976). A catalog of important Nigerian Copper-alloy Castings dated by Thermoluminescence, Archaeometry 18, 2. (1976) 135-146. 